EASTERN EUROPEAN JOURNAL OF TRANSNATIONAL RELATIONS

2018 Vol. 2 No. 1

DOI: 10.15290/eejtr.2018.02.01.03

Katarzyna Doliwa ${ }^{1}$

Faculty of Law, University of Bialystok

\title{
On the Unity of Nature in the Context of Bialowieza Forest - A Philosophical Perspective
}

\begin{abstract}
The objective of the paper is to present philosophical positions arguing the unity of nature: from the pantheistic doctrine of the Stoics and the version of pantheism proposed by G. Bruno and B. Spinoza, through the Leibniz concept which assumes that every element of nature is spiritual and capable of intentional actions, to contemporary doctrines. One of the concepts - the "deep ecology" of A. Naess, emphasizes the need for the subjective treatment of every element of nature - people, animals and plants; it postulates the specific equality of all species. The assumptions of eco-philosophy are perfectly in line with the findings of contemporary nature researchers proving that the bonds between individual elements of a given ecosystem are deeper than previously assumed, forming a complex multi-level network. A violation of the precisely developed balance can have far-reaching negative effects including for humankind. Modern philosophers stress that people responsible for shaping ecological policy should aim at protecting entire ecosystems, and they should ensure the maintenance of its balance. This philosophical message can be dedicated especially to the politicians responsible for the decision on the unprecedented logging of the Bialowieza Forest.
\end{abstract}

Key words: pantheism, unity of nature, ecophilosophy, Arne Naess, Bialowieza Forest

\section{Historical remarks}

The widely accepted contemporary conviction that all nature is one inseparable unity appeared for the first time in the works of the Stoics in the 3rd century BC. The

$1 \quad \mathrm{PhD}$ in Law, assistant professor at the Department of Philosophy and History of Law, Faculty of Law, University of Bialystok. Her main scientific interests focus on philosophy of law and logical semiotics. E-mail: kdoliwa@uwb.edu.pl. 
Stoics understood the world as a complete "one" pervaded by the rational divine principle. The world of the Stoics was of a material nature, and its reasoning and rational spirit, omnipresent, the same in all its elements - people, animals or trees was also material. The reasoning of the world, present in every smallest part of the world, created the harmony that ruled in it; everything it contained was in harmony with the inescapable will of "fate" and of "providence". (Justyńska, Justyński, 2013, p. 25). Here, man too was a part of nature governed by rational laws; in terms of the Stoics, it was the world's mind, its self-awareness or even God (Jarzębiak, 2010, pp. 173-192, Magee, 2016, p. 46).

The philosophy of the Renaissance Italian thinker and poet Giordano Bruno, who was burnt at the stake for his views in 1600 , also had a pantheistic character. The basic assumption of his philosophy was the thesis about the infinity of the universe, adopted under the influence of Copernicus' discoveries. In the face of the infinity, centuries and minutes become similar to each other, and man is neither closer to it than the ant, nor further from it than the celestial body. The new optics for perceiving the world eliminated the difference between man and what is the greatest and the smallest in nature. People wrongly, in the opinion of Bruno, treat the ants with disdain and the celestial bodies with humility; in the face of infinity, all nature's creations are equal (Tatarkiewicz, 1995, pp. 20-21).

According to Bruno, the one and homogeneous universe consists of monads. Like the point, the "mathematical minimum" is a component of space, and like an atom, the "physical minimum" is a component of matter, so a monad is the "metaphysical minimum". Each of them is unique; each of them perceives the world in their own way. Monads make every element of the world alive; its every fragment is endowed with a soul (Tatarkiewicz, 1995, p. 21). In Bruno's philosophy, living spiritual nature became the image or the revelation of God.

The eminent 17th-century thinker Gotfried Wilhelm Leibniz supported the claim of his Renaissance predecessor, proclaiming that all matter is made up of immaterial monads, "the real atoms of nature". Leibniz's monads, like Bruno's monads, were not Democritus' atoms - they were not material and had a spiritual character. Individual entities were phenomena of substance; the materiality was a form in which one monad appears to another one. Equally important, is that the Leibnizian monads - "the metaphysical points" or "the real atoms" - were not passive; they were equipped with the ability to act and perceive, and their activity was purposeful (Gut, 2004, pp. 75-76). All monads constituted a "separate cosmos" - they were closed from the outside, without windows providing them with communication with the outside world. Leibniz's monad perceived the entire world from within, recognizing it within itself; the content of their perceptions is therefore innate. Although all substances are equipped with cognitive abilities, they do not have the same access to the content of perceptions, not all are self-aware (Święczkowska, 1998, p. 25). According to Leibniz, the perception of monads may have a very different degree of 
perspicuity and clarity; some of them have imperfect and unconscious perceptions, comparable to the experiences of people in a state of deep sleep. It is the quality of perceptions that determines the difference between monads, since, although they perceive the same - the same world - they perceive it from different perspectives and with varying degrees of clarity. Monads form a hierarchy in this connection the lowest are those devoid of self-knowledge whose consciousness is dormant; the souls located lower are capable of perceptions and having memory; then monads fully self-conscious and rational are located somewhat higher; at the top of the hierarchy Leibniz placed the perfect monad - God. Although the cognitive abilities of man are the most developed, Leibniz did not refuse them to other living beings, he emphasized the spiritual nature of plants and animals - they are also made of perceiving monads. The German philosopher assumed that, although each of the monads is a closed cosmos, they all agree with each other, they live in harmony; Leibniz's world was the most harmonious and the best of all possible (Tatarkiewicz, 1995, pp. 78-80).

The view of Giordano Bruno that all nature is a unity, returned in the 17th century in the output of Benedict Spinoza. Spinoza rejected the Cartesian dualism, the division of everything that exists into spirit and matter; the system which he created is monistic, assuming that there is only one substance - God. God is an infinite and perfect being, nothing can limit it, there cannot be anything that God is not. The existence of a world not being God would limit God, so God is the world. In his More geometrico, using the mathematical method, Spinoza showed that in the universe there is unity, that God and nature are one thing, two names of the same thing. It is the same substance with infinitely many attributes. God is the substance and everything is in God, nothing can exist or be understood outside of God or Nature (Copleston, 1958, pp. 214-229).

The Spinozian deification of nature inspired the Romanticists who at the turn of the 18th to 19th century considered Spinoza one of their patrons (Magee, 2010, p. 93). The earliest influences of the Spinozism were visible among the German Romantics; he was respected by F.H. Jacobi, J.G. Herder and J.W. Goethe, later by G. Byron and P.B. Shelley; the cult of Spinoza was taken over from the Romantics by the German idealists F. Schelling and G. Hegel. In the 19th century, ecological ideas were proclaimed by R. Emerson, a representative of American Romanticism, a devotee to mystical and pantheistic faith in the spiritual unity of the world, who argued that only by merging with nature one can experience the fullness of their humanity.

Today, it is noted that the romantic philosophy, abundantly drawing on Spinoza's pantheistic idea and giving Nature a special status, is one of the significant sources of modern ecological philosophy (Kiełczewski, 2001). The attempts to compile the achievements of the creators of Romanticism and ecological philosophy show that both trends consider Nature an autonomous entity with a value in itself. According to 
the romantics, unlike in the classical tradition, man is an integral part of Nature, here understood as a self-aware, living organism. The individual "self" of a human being becomes part of a much larger whole - the universe. Like the concepts of romantic authors, ecological philosophy negates anthropocentric attitudes and refers to ideas proclaiming indivisibility, the unity of the world (Czerwiński, 2005).

In turn, in the 19th century, on the basis of liberalism and the homo oeconomicus doctrine, the conviction about the superiority of man over nature, man's total domination over it developed. It was assumed then that natural resources are unlimited and that they can be exploited in a completely arbitrary way in order to realize every human need or craving. Since the 1940s, human activity in the environment has gained a global character, and the dominant vision of the world is the technocratic worldview referring to Francis Bacon's anthropocentrism whose determinants are species' selfishness and voluntarism, unwavering faith in the possibilities of science and technology. Nature is treated in the spirit of utilitarianism, and the social interest is the main criterion for assessing things and phenomena (Matczak, 2000, pp. 7475, Albińska, 2005, pp. 145-147). In the treatment of nature and its resources, there are no moral rules, and institutions appointed to solve environmental problems are inefficient (Albińska, 2005, pp. 306-307).

\section{The unity of nature in $20^{\text {th }}$ century philosophical conceptions}

In response to the above described demanding attitude towards nature, where it is perceived only as an object of exploitation, the concept of ecophilosophy was developed, within which human life and well-being constitute the highest value, although not absolute - the value of the socio-natural environment is emphasized here. The creator of this doctrine is Henryk Skolimowski, a philosopher of language and logician, a student of Tadeusz Kotarbiński and Kazimierz Ajdukiewicz, two outstanding figures in Polish philosophy. The central issue here is the relationship between man and the environment. In Skolimowski's idea, the Earth is understood as the "spiritual sanctuary" of all life. In this idea of Earth - the temple is supposed to remind man of the ties connecting them with the world of nature; it is also to remind them of their duties towards all beings. The greatest of them to protect the diversity of life, to protect life in its every manifestation, and further - to preserve respect and have empathy towards all other creatures (Skolimowski, 1991).

Skolimowski urged a great shift, the creation of a new model of humanity defined as the ecological model which allows to achieve "the interspecies balance". His ecophilosophy became the basis for a scientific justification for attitudes conducive to nature conservation (Skolimowski, 1992, 1993).

In the 20th century, the conviction about the unity of Nature in the strongest of ways was expressed by Arne Naess, a Norwegian philosopher and logician, 
a member of the Vienna Circle and a Spinoza enthusiast. In the 1970s he became renowned as the creator and promoter of the idea of deep ecology (the term "deep ecology" was first used by Naess in 1973 in the philosophical monthly "Inquiry"), (Korbel, 2001, p. 9). Due to the dissemination of his ideas, there was a significant change in the assessment of pro-ecological attitudes, and the sensitization to nature and environmental protection issues increased among societies. Naess built his doctrine at the time civilization development began causing environmental degradation and environmentalists' protests were limited and barely audible. Prior to the Naess' manifesto, the ecological movement had been shallow ("the shallow ecology movement"), and he aimed at dealing with the problem of pollution and depletion of resources, and his main goal was to care for the health and wealth of people in developed countries (Witoszek, Brenann, 1999, p. 3). The philosophy of deep ecology is a radical and uncompromising approach - it indicates phenomena lying at the very root of today's problems related to environmental protection and suggests specific solutions.

The rejection of the "man-in-the-environment" image in favor of the relational "total- field" image is an important postulate of the deep philosophy. Man is not the center of the universe here, as in the case of the anthropocentric approach, but it part of a larger whole organized in the form of an extremely complex network of life. The fact that man is an element and not the center of the network of mutual connections fundamentally influences their perception of reality and determines their ethical decisions. The position of the human being in relation to other creatures changes, instead of the "me or you" rule, the "live and let live" principle is promoted (Witoszek, Brenann, 1999, pp. 4-7). The place of the principle of anthropocentrism is replaced by the principle of biocentrism, where life as such is the basic value.

Arne Naess aimed at proving that humanity should focus all efforts on saving Nature, while the motives for which such action would be taken are not important; what counts is achieving the goal. For the Norwegian philosopher, the whole world, both animate and inanimate, constitutes an inseparable unity, in a sense everything that surrounds man is also part of themselves. The boundary between the "I" and the "non-I" does not exist or is fluid. Nature is not only the environment of human life, but rather an indivisible system, which elements are man and Nature. Naess proclaimed that every living being - man, animal and plant - enjoys the same right to life and development. Every living being is valuable, it counts because of it alone, the value of the being cannot be measured by the degree of its usefulness to man (Naess, Haukeland, 2008, pp. 1-20). The consequence of this assumption is the recognition that a person planning any activity should take into account the effects of their actions on the natural environment, they should consider whether the consequences of their actions do not violate the vital interests of another species. Naess, in collaboration with the philosopher George Sessions, brought many years of thought on deep ecology to a close with the publication eight now famous principles: 
The prosperity and development of human and non-human life on Earth are values in themselves, immanent and innate ones, regardless of the usefulness of nonhuman life forms for humans.

The richness and diversity of life forms contribute to the realization of these values and are values in themselves.

People have no right to limit this richness and diversity unless it is to meet their vital, crucial needs.

The development of non-human life forms requires stopping the growth in the number of human population. The flourishing of human life and culture can be reconciled with such a reduction.

The human impact on other forms of life is currently too large, and this situation is rapidly deteriorating.

This requires major changes, especially economic, technological and ideological ones. The new situation will be completely different from the current one.

In the ideological sphere, it is all about limiting the growth of the material standard of living for the quality of life. Deep awareness of the difference between what is quantitatively and qualitatively great will be created.

Those who agree with the above assumptions should feel obliged to take indirect or direct actions to implement these necessary changes (Witoszek, Brenann, 1999, pp. 8-9).

The popularization of the above principles can bring tangible results. The deep ecology is considered by many a special way of perceiving the world, a special optic to which one should induce as many people as possible and ultimately politicians deciding on the shape of our interactions with nature. Its adoption by politicians may be a remedy for the ongoing ecological crisis.

The ideas of the deep ecology, alongside their enthusiasts, also have ardent critics. The objection against Naess' philosophy is that it is allegedly directed against man. Naess, along with his supporters, refute this critique by proving that people are part of nature, yet the deep ecology attributes the internal value to every being, each element of nature. According to Naess, the issue is that, while it is not difficult to appreciate and respect the values of other people, most people find it hard to see a living and feeling being in a tree. Stressing that the tree is not an object or a resource, Naess tried to get others to adopt a special attitude towards trees; let us treat them with respect and exploit them only when needed, not by a whim, let us take from nature the minimum of what we need to survive.

Contemporary findings on the unity of nature

The deep philosophy assumptions are included in the findings of Peter Wohlleben, the author of bestselling books on complex interdependencies in the world of people, animals and plants. The German naturalist notices positive changes taking place in our approach towards animals. Although we still breed them on an industrial scale, they are still used for experiments in laboratories, but at the same 
time we note that they are capable of emotions, often unusually similar to human ones, which implies giving more and more rights to animals (2016, 2017 a).

An important impact on changing the human attitude towards animals and the successive recognition of their rights was made by Peter Singer's work Animal Liberation: A New Ethics for our Treatment of Animals. At the beginning of his work, Singer states that the term "animal liberation" to many readers may sound like a mockery of the idea of liberation movements. The idea of animal rights was indeed used once to mock the equality of women. At the end of the 18th century, the concept of women's rights seemed as unlikely as the idea of granting them to animals. The idea of freeing slaves and acquiring subjective rights seemed equally difficult to understand for some people. Singer argued that the tyranny of man against animals can be compared to the enslavement of black people by white people. He argued that because animals cannot claim their rights and protest against the conditions in which they live, it is the duty of representatives of our species to speak on their behalf against those who argue that in the face of human selfish interests, morality is just an empty word. Singer and people like him fight to stop the unreflective exploitation of various species, primarily because it is unacceptable for ethical reasons. He argues that, just as women and representatives of the black race did before, animals will have their rights established, that it is inevitable and necessarily associated with the moral improvement of societies (Singer, 1975).

Nowadays, Peter Singer's forecasts begin to be confirmed. In 1999, in the German legal system, the law on improving the legal position of animals prohibiting their treatment as objects was adopted. The same applied in Polish law where the Act of 21 August 1997 on the protection of animals (consolidated text Journal of Laws of 2017, item 1840, as amended - Dz.U. 2017, poz. 1840) was introduced. The attitude involving giving up meat consumption or consciously selecting meat the is not sourced from mass breeding processes is increasingly becoming common practice. More and more often people are accepting the fact that - as the Dutch primatologist Frans de Waal showed - some animals are capable of feelings that were considered typically human - empathy or altruism. In the face of the latest research on primates, we must accept that morality is also possible in the animal world and is not exclusively a human trait $(2014,2016)$.

However, Wohlleben stresses in The Hidden Life of Trees that, while human attitudes towards animals have evolved so much in recent years, the human optic in its perception of big plants, particularly trees, has not changed, despite widespread awareness that they are living organisms. We use living beings - we kill plants, including powerful trees, for our purposes, usually in a completely unreflective way. Man's behaviour cannot be considered completely blameworthy, as man being part of nature gets nutrients from the bodies of other beings. However, Wohlleben proves that we lack proper consideration and reflection on this issue. Above all, we lack moderation in using the forest ecosystem; we could use it skillfully, without 
causing unnecessary suffering to trees - the analogy to handling livestock seems quite obvious in this context. The use of trees' "bodies" in order to produce wood or paper can be considered legitimate, as long as they are allowed to live according to their needs. The basic ones include social needs - trees should have the right to live in a forest ecosystem, the right to transmit knowledge to younger generations, and at least some of them should have the right to grow old and die a natural death. It is important that younger and older generations of trees are mixed together to grow side by side (2016).

Only recently have we become aware that plants, while lacking a brain as we know it, can, just like humans and animals communicate with each other and experience different sensations. Trees have feelings and memory; they are capable of calculating, choosing strategies for survival, and even moving in an extremely slow way. For many years, there has been a dispute among scholars on whether plants are capable of thinking in a specific way or showing some kind of intelligence. The positive answer to this question would entail stating that the differences between the world of plants and animals are not as considerable as assumed and would require treating plants with greater respect. The chances for the affirmative answer exist the research conducted at the University of Bonn Institute of Cellular and Molecular Botany proves that on the tip of the root there are structures whose operation resembles in a sense to the function of the mind being able to receive and process stimuli (Wohlleben, 2016, pp. 90-91).

Wohlleben quotes astounding facts from the life of trees: beeches, oaks, pines and spruces are social beings: they form alliances and friendships; if necessary, with the help of their root system, they share food with relatives, which allows to perceive them as superorganisms similar to anthills. This is a non-accidental and rational activity; trees growing in large groups become healthier, as they can better defend themselves against storms and the effects of heat and cold, a strategy which allows them to store water and produce humid air. For such communities, every tree is valuable, even a sick one - it should be supported until it recovers because then those who look after it can count on a rematch. (There is an analogy here to human communities - individuals form groups since it makes it easier for them to deal with external difficulties). In such communities, every individual is important, but there is also a specific hierarchy: most stumps, being tree remains, will decay after a few decades, but some remains of the trees enjoying special sympathy from others are kept alive for several centuries - relatives persistently provide water and mineral substances to the patriarchs. It is significant that such friendships occur only in natural forests and such dependencies are not observed in timber forests. Repotting permanently damages roots, so trees in artificially created forests do not establish contacts, they in effect loners; they become incapable of cooperating, do not create communities, and cannot count on mutual assistance from their neighbours (2016, pp. 12-15). 
A phenomenon occurring only in natural forests is also "bringing up" young trees by their parents through limiting the amount of light reaching them. Adult trees cover the sky with their crowns in such a way that only 3 percent of sunlight reaches their offspring. Such "behaviour" of parents slows down photosynthesis and limits the growth of offspring; it would seem that this is done to the detriment of the young ones. However, it turns out that the limitation of access to light and slow growth in youth ensures they reach old age. Trees that grow slowly, surrounded by a protective umbrella of ancestral crowns, have special wood cells inside their trunks - there is little air in them which makes the tree flexible and thus more resistant to storms. A further measure to ensure longevity is provided by their ancestors' in making them resistant to fungal attack, enhancing their resistance to wounds and giving them the ability to heal wounds quickly. Trees whose childhood and youth extend over a very long period of time for their long-term benefit, are not deprived of their parents' care, they are constantly "fed" through the root system (Wohlleben, 2016, pp. 42-44).

Another previously unknown fact from the life of trees, allowing to see them as social beings, is that woodland communities possess a quasi-language - a smell code. Trees whose leaves have been attacked by caterpillars for example send a special warning signal in the form of a gas emission to their fellows, so that they can themselves prepare for the attack by saturating their leaves with toxic substances to discourage pests. Similar signals are sent via root networks, increasing the chances that all surrounding trees of the same species will be informed of the threat. Such messages are sent not only by chemical codes, but also by electrical impulses at the speed of one centimeter per second (a similar rate that stimuli are transmitted by jellyfish). The range of this "information network", referred to in scientific circles as the "Wood-Wide-Web", is indeed extremely wide - in its activity mycelial strands are included helping transmit information on drought, insects or other dangerous events. It is significant that crop plants are "silent" and "deaf", as a result of breeding method they lose the ability to communicate with other members of their community (Wohlleben, 2016, pp. 16-23).

Unfortunately, 95 percent of current practice in forestry management in Central and Eastern European countries is different than it should be; instead of the harmonious "breeding of trees" in their natural environment, systematic logging with the use of heavy equipment takes place. The country whose solutions are of a model nature and where trees are today respected, is Switzerland. The federal constitution in article 120 entitled "Genetic technology with regard to non-human life" provides that the competent authorities shall issue provisions on handling of semen and genetic material of animals, plants and other organisms, taking into account the dignity of the creatures. Such regulation allows perceiving forests above all as a complex ecosystem, a living space for many species, connected with each other by a series of interdependencies. 


\section{Case study of Bialowieza Forest}

The exemplification of proceedings in contradiction to the model Swiss solution is the case of the Bialowieza Forest, where tree logging violates all rights of a living superorganism postulated by philosophers and ecologists. The actions of the Polish government seem to be inspired by the naive interpretation of the Old Testament passage: "Be fruitful and multiply and fill the earth and subdue it, and have dominion over the fish of the sea and over the birds of the heavens and over every living thing that moves on the earth" (Genesis, 1:28). By the decision of the Polish authorities of 25 March 2016 the annex to the forest management plan for the Bialowieza Forest Inspectorate was approved, allowing for a threefold increase in logging, including logging in areas previously excluded from human intervention. The reason for this was to fight the European spruce bark beetle (Ips typographus), a spruce pest. It is significant that the Court of Justice of the European Union considered such action illegal and its purpose as typically commercial. The act of the Polish authorities threatens species in need of old stands to exist. It also interferes strongly with the population of trees by cutting down the oldest specimens that comprised the living "memory" of the tree community and hence the most important part of the memory of the forest as a whole. The European Commission proves that the bark beetle gradation is a typical phenomenon and the forest can deal with it on its own, such a situation has already occurred in its history many times.

Adam Wajrak, journalist and activist working for nature conservation, from years living in the heart of the Forest, reports the enormous devastation of the Bialowieza Forest. With concern, he talks about the destruction of a centuries-old forest planted by no-man. Every day up to three hundred trees were cut down using heavy equipment; next to the spruces attacked by the bark beetle, young trees of various species: spruces, hornbeams, maples and oaks, all unaffected by the insect, were also cut down. Many big oaks fell when their support from the dry spruces was removed. Natural regeneration in these areas will not be possible for a very long time, as it requires dead trees to protect new growth from herbivores while at the same time forming a foundation for the new generation of trees. The habitats of dozens of species protected by EU law, including the extremely rare three-toed woodpeckers, were destroyed. The logging will inevitably result in a change in the microclimate, and by that, many species associated with the depth of the forest will also lose their natural habitat (Korzeniowska and others).

The pretext for cutting down the trees in Bialowieza Forest was the so-called struggle against bark beetle infestation, presented by its initiators as a terrifying threat to the spruces. However, to put that claim in perspective, in a natural primeval forest free of artificial plantings, the spruce bark beetle is an eliminator of ill and weakened specimens; it only harms those trees whose health is for some reason strained. A weakened tree singled out by the beetle to become its victim, later 
provides a home for a myriad of microorganisms and insects, and therewith, a source of food for a wide variety of small mammals and birds including the woodpecker. The reason beetle swarming occurs (a situation where in addition to attacking unhealthy spruce they also attack healthy trees), only takes place when man intervenes in the ecosystem and significantly disturbs the previously maintained balance, i.e. by the emission of harmful substances that change the forest's microclimate, by artificial planting or by planting non-native species and the like. Spruce forests destroyed by the bark beetle are a place where in the future indigenous species of deciduous trees will be reborn; bark beetles are not only gravediggers but also, in a sense, forest midwives (Wohlleben, 2017 b, pp. 82-91).

\section{Summary}

It seems that the intuitions of the Stoics who wrote about the reason pervading the whole Nature and praised its prevailing order and harmony and its ability to regulate and organize itself, were right. As Bruno, Leibniz and Spinoza agreed upon, the whole of nature operates like clockwork; it is ordered and within that order every being has its strictly determined function, one piece is linked with another and all are interconnected to form an intricately woven network. The deep ties found today in the world of nature are invisible to an ordinary observer; they occur simultaneously on many levels, they combine organisms as diverse as bacteria, fungi and trees. These mutual, extremely complicated relationships between all creatures inhabiting a given ecosystem keep it in a state of equilibrium. Even the smallest human intervention in this natural world can, and often does, have serious consequences; if our human actions are not truly necessary, it is best - in accordance with Naess' deep philosophy - to leave well alone. If they are necessary, they should be carefully thought through, so that their negative effects are as harmless as possible to the flora and fauna involved. Such behaviour requires a permanent change in man's attitude towards nature - a partnership arrangement combined with the change of social lifestyle from "must have" to "mustn't take" would be desirable.

\section{REFERENCES:}

Albińska, E. (2005). Człowiek w środowisku przyrodniczym i społecznym. Lublin: Wydawnictwo KUL.

Copleston, F. (1958). History of Philosophy, v. IV, Descartes to Leibniz. London: Search Press, New Jersey: Paulist Press

Czerwiński, G. (2005). Przyroda dzika - przyroda romantyczna. Czy można potraktować romantyków jako dziewiętnastowiecznych rzeczników filozofii ekologicznej? Dzikie Życie, 132(6).

Gut, P. (2004). Leibniz. Myśl filozoficzna w XVII wieku. Wrocław: Wydawnictwo Uniwersytetu Wrocławskiego. 


\section{EASTERN EUROPEAN JOURNAL OF TRANSNATIONAL RELATIONS}

Jarzębiak, J., (2010). Zarys teologii stoickiej, Acta Universitatis Lodziensis, Folia Philosophica 23, 173-192.

Justyńska, I., Justyński, J. (2013). Historia myśli socjologiczno-ekonomicznej. Warszawa: Wolters Kluwer.

Kiełczewski, D. (2001). Ekologia społeczna. Białystok: Wydawnictwo Ekonomia i Środowisko.

Konstytucja Szwajcarii, tytuł III, displayed at: http://libr.sejm.gov.pl/tek01/txt/konst/szwajcaria.html

Korbel, A. J. (2001). O przyrodzie i człowieku. Pracownia na rzecz Wszystkich Istot.

Korzeniowska, K., Pawłowska, D., Kopeć, J., Makarenko V., Mierzejewski, M., Ochota, R., Uhlig, D., Wajrak, A., Wyrok na puszcze, displayed at: https://infografiki.wyborcza.pl/wyrok-na puszcze/ desktop.html?utm_source=SARE\&utm_medium=email\&utm_campaign=puszcza

Magee, B. (2016). The Story of Philosophy. Dorling Kindersley Publishing.

Matczak, P. (2000). Problemy ekologiczne jako problemy spoteczne. Poznań: Wydawnictwo Naukowe UAM.

Naess, A., Haukeland, P. I., (2008). Life's Philosophy: Reason and Feeling in a Deeper World. Athens and London: University of Georgia Press.

Naess, A. (1993). Spinoza and the deep ecology movement. Eburon Academic Publishers. Singer, P. (1975). Animal Liberation: A New Ethics for our Treatment of Animals. New York: Review/Random House.

Old Testament, Standard English Version, displayed at: http://biblehub.com/genesis/1-28.htm

Skolimowski, H. (1993). Filozofia żyjaca. Eko-filozofia jako drzewo życia. Warszawa: Pusty Obłok.

Skolimowski, H. (1992). Nadzieja matkq mqdrych. Eseje o ekologii. Warszawa: Akapit Press.

Skolimowski, H. (1991). Ocalić Ziemię - Świt filozofii ekologicznej. Warszawa: Wydawnictwo K. Staszewskiego.

Święczkowska, H. (1998). Harmonia Linguarum. Język i jego funkcje w filozofii Leibniza. Białystok: Wydawnictwo UwB.

Tatarkiewicz, W. (1995). Historia filozofii, t. 2. Warszawa: PWN.

Ustawa z dnia 21 sierpnia 1997 r. o ochronie zwierząt (tekst jedn. Dz. U. z 2017 r., poz. 1840, ze zm.). displayed at: http://prawo.sejm.gov.pl/isap.nsf/download.xsp/WDU19971110724/U/ D19970724Lj.pdf

Witoszek, N., Brennan, A. (Eds.). (1999). Philosophical Dialogues: Arne Naess and the Progress of Ecophilosophy. New York, Oxford: Rowmann and Littlefield Publishers, Inc. Lanham, Boulder.

Wohlleben, P. (2017). Duchowe życie zwierzqt. Kraków: Otwarte.

Wohlleben, P. (2017). Nieznane więzi natury. Kraków: Otwarte.

Wohlleben, P. (2016). Sekretne życie drzew. Kraków: Otwarte.

De Waal, F. (2016). Are We Smart Enough to Know How Smart Animals Are? New York: W. W. Norton \& Company.

De Waal, F. (2014). Evolved Morality. The Biology and Philosophy of Human Conscience. Leiden, Boston: Brill. 
ON THE UNITY OF NATURE IN THE CONTEXT OF BIALOWIEZA FOREST ...

De Waal, F. (2013). The Bonobo and the Atheist. In Search of Humanism Among the Primates. New York: W. W. Norton \& Company.

Waloszczyk, K. (1996). Kryzys ekologiczny w świetle ekofilozofii. Łódź: Wydawnictwo Politechniki Łódzkiej. 